\title{
Emended descriptions of Geobacillus thermoleovorans and Geobacillus thermocatenulatus
}

Correspondence

An Coorevits

an.coorevits@hogent.be
Anna E. Dinsdale, ${ }^{1}$ Gillian Halket, ${ }^{1}$ An Coorevits, ${ }^{2,3}$ Anita Van Landschoot, ${ }^{2,3}$ Hans-Jürgen Busse, ${ }^{4}$ Paul De Vos ${ }^{3}$ and Niall A. Logan ${ }^{1}$

${ }^{1}$ Department of Biological and Biomedical Sciences, Glasgow Caledonian University, Cowcaddens Road, Glasgow, G4 OBA, UK

${ }^{2}$ Department of Applied Engineering Sciences, Laboratory of Biochemistry and Brewing, University College Ghent, Schoonmeersstraat 52, B-9000 Ghent, Belgium

${ }^{3}$ Laboratory of Microbiology, Department of Biochemistry and Microbiology, Ghent University, K.L. Ledeganckstraat 35, B-9000 Ghent, Belgium

${ }^{4}$ Institut für Bakteriologie, Mykologie \& Hygiene, Veterinärmedizinische Universität, Veterinärplatz 1, A-1210 Vienna, Austria

Nineteen thermophilic, aerobic, endospore-forming bacterial strains were subjected to $16 \mathrm{~S}$ rRNA gene sequence analysis. Eight of these strains had been received as cultures of Geobacillus kaustophilus, G. lituanicus, G. stearothermophilus, 'G. thermoleovorans subsp. stromboliensis', G. vulcani, 'Bacillus caldolyticus', 'B. caldotenax' and 'B. caldovelox', but they showed close relationships with the type strain of $G$. thermoleovorans, as did two other strains received as $G$. thermoleovorans. All strains underwent further taxonomic analysis by API and other phenotypic tests and fatty acid methyl ester analysis, and selected strains were analysed for their polar lipids and for DNA relatedness. The 11 strains that formed the G. thermoleovorans $16 \mathrm{~S}$ rRNA cluster also showed some phenotypic similarities, and DNA relatedness data support the reassignment of the strains received as G. kaustophilus, G. lituanicus, 'G. thermoleovorans subsp. stromboliensis', G. vulcani, 'B. caldolyticus', 'B. caldotenax' and ' $B$. caldovelox', and one of the $G$.

stearothermophilus strains, as members of the species $G$. thermoleovorans. Four other strains received as G. kaustophilus were misnamed; two were identified as G. stearothermophilus and two appeared to be closely related to Anoxybacillus rupiensis. One strain received as $G$. stearothermophilus remained unidentified. On the basis of a single strain, Geobacillus thermocatenulatus was shown to represent a distinct species, but study of the type strain of Geobacillus gargensis showed this species to be a later heterotypic synonym of Geobacillus thermocatenulatus. Emended descriptions of Geobacillus thermoleovorans and Geobacillus thermocatenulatus are therefore presented.
Following the discovery of novel thermophilic, aerobic endospore-formers in petroleum reservoirs, Nazina et al. (2001) proposed that the six species belonging to 16S rRNA group 5 of Ash et al. (1991) should be accommodated in a

The GenBank/EMBL/DDBJ accession numbers for the 16S rRNA gene sequences of Geobacillus strains under study are FN428637, FN428638, FN428642, FN428645, FN428646, FN428671, FN428672, FN428674, FN428675, FN428683, FN428684, FN428686, FN428693-FN428696, FN538989, AM988775 and AM988776, as detailed in Table 1.

Three supplementary figures are available with the online version of this paper. new genus, Geobacillus, along with two novel species, Geobacillus subterraneus and G. uzenensis. Geobacillus thus contained eight species: Geobacillus stearothermophilus (the type species), G. kaustophilus, G. subterraneus, G. thermocatenulatus, G. thermodenitrificans, G. thermoglucosidasius, $G$. thermoleovorans and G. uzenensis. For many years, the taxonomic positions of G. kaustophilus and G. thermocatenulatus, along with those of 'Bacillus caldolyticus', ' $B$. caldotenax' and ' $B$. caldovelox', have been unclear. Metabolic studies and phage typing by Sharp et al. (1980) also revealed close relationships between these species. White et al. (1993) considered whether ' $B$. caldolyticus', 'B. caldotenax' and 'B. caldovelox' (Heinen \& Heinen, 1972) 
were synonymous, and they recommended the revival of ' $B$. caldotenax', but their DNA relatedness data were inconclusive. They also proposed an emended description of Bacillus kaustophilus. The 16S rRNA gene sequence studies of Rainey et al. (1994) showed that B. kaustophilus, $B$. thermoleovorans, ' $B$. caldolyticus', ' $B$. caldotenax' and ' $B$. caldovelox' were closely related and that this group was related to Bacillus thermocatenulatus. Sunna et al. (1997) proposed the merger of all these species on the basis of 72 $88 \%$ DNA relatedness between representative strains. Nazina et al. (2004) did not support such a merger, however, as they found only 47-54\% DNA relatedness between strains of G. kaustophilus, G. thermoleovorans and G. thermocatenulatus. Nazina et al. (2004) also proposed the novel species Geobacillus gargensis, and the transfer of Bacillus vulcani (Caccamo et al., 2000) to Geobacillus on the basis of $99.4 \% 16 \mathrm{~S}$ rRNA gene sequence similarity and $55 \%$ DNA relatedness with the type strain of G. kaustophilus. Other taxa showing high 16S rRNA gene sequence similarities with G. kaustophilus, G. thermocatenulatus and G. thermoleovorans are Geobacillus lituanicus (Kuisiene et al., 2004), 'G. thermoleovorans subsp. stromboliensis' (Romano et al., 2005) and 'G. zalihae' (Abd Rahman et al., 2007). The present study subjected strains of G. gargensis, G. kaustophilus, G. lituanicus, G. stearothermophilus, G. thermocatenulatus, G. thermoleovorans, ' $G$. thermoleovorans subsp. stromboliensis', G. vulcani, 'B. caldolyticus', 'B. caldotenax' and ' $B$. caldovelox' to a polyphasic taxonomic study, in order to resolve the taxonomic confusion.

\section{Bacterial strains}

The strains included in the study are listed in Table 1. Strains were grown on trypticase soy agar (TSA; Oxoid), unless otherwise stated, and incubated at 50 or $60{ }^{\circ} \mathrm{C}$ for $18-24 \mathrm{~h}$. An exception was G. lituanicus R-35645 which was grown on nutrient agar. Both media were supplemented with $5 \mathrm{mg} \mathrm{MnSO} \mathrm{l}^{-1}$ to encourage sporulation, and sporulated cultures were maintained at $3-5{ }^{\circ} \mathrm{C}$.

\section{Phenotypic characterization}

Colonial characters were recorded, and cellular and sporangial morphologies were observed by phase-contrast microscopy. Gram reaction, temperature and $\mathrm{pH}$ ranges, $\mathrm{NaCl}$ tolerance, production of catalase and oxidase and starch and casein hydrolysis were tested by the methods of Logan \& De Vos (2009). Characterization tests for each strain were performed in duplicate and repeated if the results were ambiguous. Species represented by single strains were tested in triplicate. Biochemical characters were tested following the methods of Logan \& Berkeley (1984) and Allan et al. (2005), and data were subjected to numerical taxonomic analysis using BioNumerics 5.1 software (Applied Maths) using Gower's general similarity coefficient $\left(S_{\mathrm{G}}\right.$; Gower, 1971) and UPGMA cluster analysis. Test error was calculated from mean similarities of several duplicated strains and the probability of error $(P)$ for an individual test was $0.25 \%$.

\section{Fatty acid methyl ester (FAME) analysis}

For FAME analysis, the method of Vauterin et al. (1991) was followed, and profiles were identified using the Microbial Identification System software version 3.8. Cells were grown on TSA at $52{ }^{\circ} \mathrm{C}$ for $24 \mathrm{~h}$ as recommended in the Microbial Identification System instructions (Microbiol ID).

\section{Polar lipids}

Polar lipids of type and reference strains were extracted and separated by using two-dimensional TLC according to Tindall (1990a, b). Total lipids were visualized by spraying with molybdatophosphoric acid and further characterized by spraying with ninhydrin (specific for amino groups), molybdenum blue (specific for phosphates) and $\alpha$ naphthol (specific for sugars).

\section{$16 S$ rRNA gene sequencing}

Partial 16S rRNA gene sequences were generated as described by Heyrman \& Swings (2001). Sequencing products were purified with the Big Dye XTerminator Purification kit (Applied Biosystems) according to the manufacturer's instructions, using sequential pipetting and a MixMate (Eppendorf) shaking device. Sequence analysis was performed using a 3100 DNA Sequencer (Applied Biosystems) according to the manufacturer's guidelines. Sequences were assembled and compared using BioNumerics 5.1 software. Phylogenetic trees were constructed using the maximum-likelihood, maximum-parsimony and neighbour-joining methods, based on these partial 16S rRNA gene sequences, together with publicly available sequences of type strains within the genus Geobacillus. Alignment and clustering of sequences was performed using MEGA4 (Tamura et al., 2007) and PhyML (Guindon \& Gascuel, 2003). The maximum-likelihood tree is represented in Fig. 1, and is supported by the maximumparsimony and neighbour-joining trees (Supplementary Figs S1 and S2, available in IJSEM Online).

\section{DNA-DNA relatedness and DNA $\mathrm{G}+\mathrm{C}$ content}

DNA was prepared and purified as described by Logan et al. (2000). Hybridizations were performed using a modification (Willems et al., 2001) of the microplate method described by Ezaki et al. (1989) with a reassociation temperature of $37{ }^{\circ} \mathrm{C}$. The $\mathrm{G}+\mathrm{C}$ contents of the DNAs were determined by HPLC (Mesbah et al., 1989), using further specifications given by Logan et al. (2000).

Our findings supported earlier proposals for merging the species G. kaustophilus, G. thermoleovorans, 'B. caldolyticus', ' $B$. caldotenax' and ' $B$. caldovelox'. The $16 \mathrm{~S}$ rRNA gene sequences of the type strains G. kaustophilus R-35638 $8^{\mathrm{T}}$, G. lituanicus $\mathrm{R}-35645^{\mathrm{T}}$ and G. thermoleovorans $\mathrm{R}-35636^{\mathrm{T}}$ and of ' $G$. thermoleovorans subsp. stromboliensis' R-35650 clustered at $99.9 \% S_{\mathrm{P}}$ (pairwise similarity). 'B. caldolyticus' 
Table 1. Overview of strains included in this study

Culture collections: ATCC, American Type Culture Collection, Manassas, VA, USA; Atkinson, A. Atkinson, Centre for Applied Microbiology and Research (CAMR), Porton Down, UK; B, Bacillus Collection at Glasgow Caledonian University, Glasgow, UK; CIP, Collection de l'Institut Pasteur, Paris, France; DSM(Z), Deutsche Sammlung von Mikroorganismen und Zellkulturen, Braunschweig, Germany; Kuisiene, N. Kuisiene, Vilnius University, Lithuania; LMG, Belgian Coordinated Collections of Microorganisms, Bacteria Collection, Laboratorium voor Microbiologie, Universiteit Gent, Belgium; LUDA, Leeds University Department of Agriculture, Leeds, UK; NCA, National Canners Association, Berkeley, CA, USA; Sharp, R. J. Sharp, CAMR, Porton Down, UK; R, Research Collection of the Laboratory of Microbiology, Universiteit Gent, Ghent, Belgium; VKM, All-Russian Collection of Microorganisms, Institute of Biochemistry and Physiology of Microorganisms, Russian Academy of Sciences, Pushchino, Russia.

\begin{tabular}{|c|c|c|c|c|c|}
\hline Name as received & $\begin{array}{l}\text { Identity based } \\
\text { on this study }\end{array}$ & $\begin{array}{c}\text { Subculture } \\
\text { used }\end{array}$ & Other designations & Source & $\begin{array}{l}16 S \text { rRNA } \\
\text { gene sequence } \\
\text { accession no. }\end{array}$ \\
\hline 'B. caldolyticus' & G. thermoleovorans & $\mathrm{R}-32508$ & $\begin{array}{l}\text { LMG 17975, DSM 405, B0211, } \\
\text { Heinen YT-P }\end{array}$ & $\begin{array}{l}\text { Superheated pool water, } \\
\text { USA; Atkinson }\end{array}$ & FN428646 \\
\hline 'B. caldotenax' & G. thermoleovorans & $\mathrm{R}-32507$ & $\begin{array}{l}\text { LMG 17974, DSM 406, B0212, } \\
\text { Heinen YT-G }\end{array}$ & $\begin{array}{l}\text { Superheated pool water, } \\
\text { USA; Atkinson }\end{array}$ & FN428645 \\
\hline 'B. caldovelox' & G. thermoleovorans & $\mathrm{R}-32499$ & $\begin{array}{l}\text { LMG 14463, DSM 411, B0213, } \\
\text { Heinen YT-F }\end{array}$ & $\begin{array}{l}\text { Superheated pool water, } \\
\text { USA; Atkinson }\end{array}$ & FN428638 \\
\hline G. gargensis & G. thermocatenulatus & $\mathrm{R}-35649^{\mathrm{T}}$ & 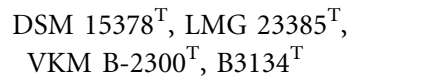 & $\begin{array}{l}\text { Garga hot spring, Eastern } \\
\text { Siberia, Russia; DSMZ }\end{array}$ & FN428695 \\
\hline G. kaustophilus & G. thermoleovorans & $\mathrm{R}-35638^{\mathrm{T}}$ & $\begin{array}{l}\text { LMG } 9819^{\mathrm{T}}, \text { DSM } 7263^{\mathrm{T}}, \\
\text { ATCC } 8005^{\mathrm{T}}, \mathrm{B} 3061^{\mathrm{T}}\end{array}$ & Pasteurized milk; DSMZ & FN428686 \\
\hline G. kaustophilus & G. stearothermophilus & $\mathrm{R}-32635$ & B1552, Sharp 10007 & Soil from Wales, UK; Sharp & FN428672 \\
\hline G. kaustophilus & G. stearothermophilus & $\mathrm{R}-32504$ & B1555, LUDA T28 & Wolf & FN428642 \\
\hline G. kaustophilus & Anoxybacillus rupiensis & $\mathrm{R}-32636$ & B2598, Sharp 10332 & $\begin{array}{l}\text { Near Lake Taupo, } \\
\text { New Zealand; Sharp }\end{array}$ & AM988775 \\
\hline G. kaustophilus & Anoxybacillus rupiensis & $\mathrm{R}-32637$ & B2599, Sharp 10315 & $\begin{array}{l}\text { Near Lake Taupo, } \\
\text { New Zealand; Sharp }\end{array}$ & AM988776 \\
\hline G. lituanicus & G. thermoleovorans & $\mathrm{R}-35645^{\mathrm{T}}$ & $\begin{array}{l}\text { DSM } 15325^{\mathrm{T}} \text {; LMG } 23033^{\mathrm{T}} \text {, } \\
\text { VKM B-2294 }^{\mathrm{T}}, \mathrm{B} 3094^{\mathrm{T}}\end{array}$ & Lithuanian oilfield; Kuisiene & FN428693 \\
\hline G. stearothermophilus & & $\mathrm{R}-35646^{\mathrm{T}}$ & $\begin{array}{l}\text { LMG } 6939^{\mathrm{T}} ; \text { DSM } 22^{\mathrm{T}} ; \text { ATCC } \\
12980^{\mathrm{T}}, \mathrm{B} 3117^{\mathrm{T}}\end{array}$ & $\begin{array}{l}\text { Deteriorated canned food; } \\
\text { DSMZ }\end{array}$ & FN428694 \\
\hline G. stearothermophilus & G. thermoleovorans & $\mathrm{R}-32642$ & $\begin{array}{l}\text { DSM 3299, ATCC 15952, } \\
\text { B3122, NCA } 5520\end{array}$ & DSMZ & FN428674 \\
\hline G. stearothermophilus & Geobacillus sp. & R-32643 & $\begin{array}{l}\text { DSM 13240, CIP 106956, } \\
\text { B3124 }\end{array}$ & $\begin{array}{l}\text { Hot springs, Yellowstone } \\
\text { National Park, USA; DSMZ }\end{array}$ & FN428675 \\
\hline G. thermocatenulatus & & $\mathrm{R}-35648^{\mathrm{T}}$ & $\begin{array}{c}\text { DSM } 730^{\mathrm{T}}, \mathrm{LMG} 19007^{\mathrm{T}} \\
\text { VKM B- } 1259^{\mathrm{T}}, \mathrm{B} 3129^{\mathrm{T}}\end{array}$ & $\begin{array}{l}\text { Coating inside tube of hot-gas } \\
\text { well, Southern Urals, USSR; } \\
\text { DSMZ }\end{array}$ & FN538989 \\
\hline G. thermoleovorans & & $\mathrm{R}-35636^{\mathrm{T}}$ & $\begin{array}{c}\text { LMG } 9823^{\mathrm{T}}, \text { DSM } 5366^{\mathrm{T}}, \\
\text { ATCC } 43513^{\mathrm{T}}, \mathrm{B} 3059^{\mathrm{T}}\end{array}$ & $\begin{array}{l}\text { Soil near hot water effluent, } \\
\text { Bethlehem, USA; DSMZ }\end{array}$ & FN428684 \\
\hline G. thermoleovorans & & $\mathrm{R}-32630$ & DSM 11667, B3131, Sunna HSR & Soil, Jordan; DSMZ & FN428671 \\
\hline G. thermoleovorans & & $\mathrm{R}-32498$ & $\begin{array}{l}\text { DSM 11668, B3132, } \\
\text { Antranikian K-3d }\end{array}$ & Hot spring, Japan; DSMZ & FN428637 \\
\hline $\begin{array}{l}\text { 'G. thermoleovorans } \\
\text { subsp. stromboliensis' }\end{array}$ & G. thermoleovorans & $\mathrm{R}-35650$ & $\begin{array}{l}\text { DSM 15392, ATCC BAA-979, } \\
\text { B3135, Pizzo }\end{array}$ & $\begin{array}{l}\text { Soil close to crater of } \\
\text { Stromboli, Italy; DSMZ }\end{array}$ & FN428696 \\
\hline G. vulcani & G. thermoleovorans & $\mathrm{R}-35635^{\mathrm{T}}$ & $\begin{array}{l}\text { DSM } 13174^{\mathrm{T}}, \text { LMG } 19852^{\mathrm{T}} \text {, CIP } \\
106305^{\mathrm{T}}, \mathrm{B} 3058^{\mathrm{T}},{\text { Caccamo } 3 \mathrm{~S}-1^{\mathrm{T}}}^{2}\end{array}$ & $\begin{array}{l}\text { Sediment, Vulcano-La Roya } \\
\text { marine thermal vent, Eolian } \\
\text { Islands, Italy; DSMZ }\end{array}$ & FN428683 \\
\hline
\end{tabular}

$\mathrm{R}-32508$, 'B. caldotenax' R-32507 and 'B. caldovelox' R32499 clustered together at $99.8 \% S_{\mathrm{P}}$ and joined the $G$. thermoleovorans cluster at $99.8 \% S_{\mathrm{P}}$ (Fig. 1), with $G$. vulcani $\mathrm{R}-35635^{\mathrm{T}}$ joining the cluster at $99.7 \% S_{\mathrm{P}}$ and $\mathrm{R}-$ 32642 (received as G. stearothermophilus) joining at $99.6 \%$ $S_{\mathrm{P}}$. Reference strains for species within the group showed over $71.5 \%$ DNA relatedness: values for hybridization with
G. thermoleovorans $\mathrm{R}-35636^{\mathrm{T}}$ for the type strains of $G$. kaustophilus, G. lituanicus and G. vulcani and for strains of 'B. caldolyticus', 'B. caldotenax', 'B. caldovelox' and ' $G$. thermoleovorans subsp. stromboliensis' were 82.4, 81.0, 79.4, 80.7, 75.8, 71.5 and $76.6 \%$, respectively. These DNA relatedness data indicate that Geobacillus kaustophilus (Priest et al. 1989) Nazina et al. 2001, Geobacillus lituanicus 


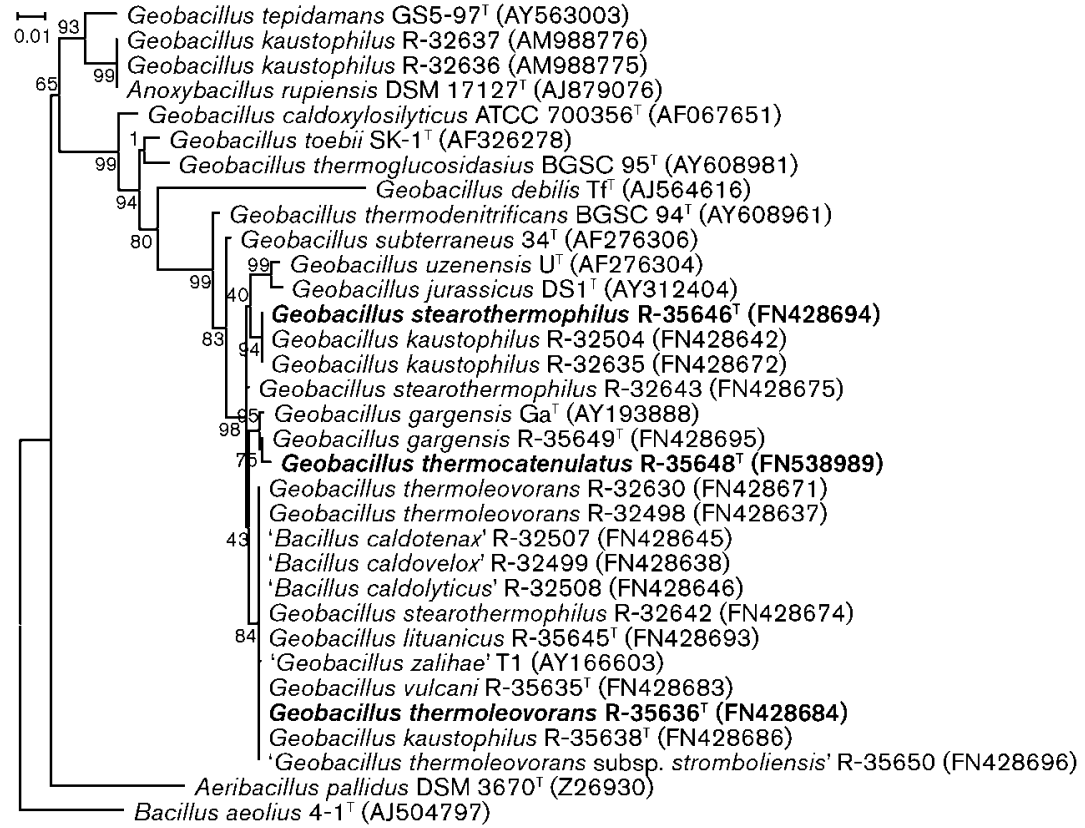

Fig. 1. Maximum-likelihood tree based on partial 16S rRNA gene sequences (1363 bp) of 19 Bacillus and Geobacillus strains. The 16S rRNA gene sequence of Bacillus aeolius 4-1 ${ }^{\top}$ (GenBank accession no. AJ504797) was selected as an outgroup to root the tree. Alignment and clustering of sequences was performed using MEGA4 and PhyML. aLRT values are shown at branch points. Accession numbers are given in parentheses. All strains within the tree are represented by their names as received. The type strains, as studied, of G. stearothermophilus, G. thermocatenulatus and $G$. thermoleovorans are indicated in bold. Bar, 0.01 substitutions per nucleotide position.
Kuisiene et al. 2004 and Geobacillus vulcani (Caccamo et al. 2000) Nazina et al. 2004 are later heterotypic synonyms of Geobacillus thermoleovorans (Zarilla and Perry 1988) Nazina et al. 2001, and that 'B. caldolyticus', 'B. caldotenax', ' $B$. caldovelox' and ' $G$. thermoleovorans subsp. stromboliensis' are also members of $G$. thermoleovorans. These conclusions are consistent with the phylogenetic data of Nazina et al. (2005) and Zeigler (2005).

Only 'B. caldolyticus' R-32508, 'B. caldotenax' R-32507 and ' $B$. caldovelox' R-32499 showed significant phenotypic similarities, clustering at $90 \% S_{\mathrm{G}}$ (not shown), while joining with $G$. thermoleovorans $\mathrm{R}-35636^{\mathrm{T}}$ at less than $85 \%$ $S_{\mathrm{G}}$. G. kaustophilus $\mathrm{R}-35638^{\mathrm{T}}$ and ' $\mathrm{G}$. thermoleovorans subsp. stromboliensis' R-35650 showed rather few phenotypic similarities with the $G$. thermoleovorans type strain. The considerable phenotypic diversity between these organisms makes a practically useful description difficult to write; indeed, Sunna et al. (1997) said that an emended Bacillus thermoleovorans would be 'characterized by its phenotypic heterogeneity and its genotypic homogeneity'. Further work, with more isolates, might allow biotypes to be discerned within the species.

Polar lipid data were analysed for the type strains $G$. kaustophilus $\mathrm{R}-35638^{\mathrm{T}}$, G. lituanicus $\mathrm{R}-35645^{\mathrm{T}}$, G. stearothermophilus R-35646 ${ }^{\mathrm{T}}$, G. thermoleovorans $\mathrm{R}-35636^{\mathrm{T}}$ and G. vulcani R-35635' and for ' $B$. caldolyticus' R-32508, ' $B$. caldotenax' R-32507 and ' $B$. caldovelox' R-32499. Polar lipid profiles were very similar for all strains, and displayed diphosphatidylglycerol, phosphatidylglycerol, phosphatidylethanolamine, an unknown aminophosphoglycolipid and some unknown aminolipids, a phosphoaminolipid, probably phosphatidylserine, and a lipid in minor amounts. Our polar lipid profiles for Geobacillus strains, including that of the type species G. stearothermophilus, included phosphatidylglycerol, whereas Miñana-Galbis et al. (2010) reported its absence from the type strain of G. stearothermophilus. The polar lipid profile of the type strain of G. thermoleovorans is shown in Supplementary Fig. S3. The polar lipid profiles of the species of Geobacillus here examined are clearly distinguished from those of other endospore-forming taxa that show meso-diaminopimelic acid in the peptidoglycan and a quinone system with the predominant compound menaquinone MK-7, such as Bacillus, Paenibacillus, Cohnella (Kämpfer et al., 2006) and Falsibacillus (Zhou et al., 2009). Bacillus subtilis and Paenibacillus polymyxa, the type species of their respective genera, exhibit glycolipids not detectable in Geobacillus species but lack the aminophosphoglycolipid found in Geobacillus. Cohnella species can be distinguished from Geobacillus based on the absence of the aminophosphoglycolipid and the presence of two aminophospholipids (PN3 and PN4) and phospholipid PL2 (Kämpfer et al., 2006). Whether the unidentified aminolipid AL2 of Geobacillus corresponds to lysyl-phosphatidylglycerol detected in Cohnella is still to be examined. In contrast to Geobacillus, Falsibacillus (Zhou et al., 2009) exhibits two other aminophosphoglycolipids, two phosphoglycolipids and a glycolipid. An emended description of G. thermoleovorans is given below, and characters that differentiate the species from other members of the genus are shown in Table 2 .

In the study of Abd Rahman et al. (2007), the proposed type strain of ' $G$. zalihae' clustered with members of the $G$. thermoleovorans group and showed 68.2 and 73.6\% DNA relatedness, respectively, with the type strains of $G$. thermoleovorans and G. kaustophilus, so this strain appears to be yet another representative of $G$. thermoleovorans. This was confirmed by a $16 \mathrm{~S}$ rRNA gene sequence similarity of 


\section{Table 2. Differentiation table}

Species: 1, G. stearothermophilus ( $n=15) ; 2$, G. caldoproteolyticus $(n=1) ; 3$, G. caldoxylosilyticus $(n=1) ; 4$, G. debilis $(n=1)$; 5 , G. jurassicus $(n=2)$; 6, G. subterraneus $(n=1) ; 7$, G. tepidamans $(n=1) ; 8$, G. thermocatenulatus $(n=2) ; 9$, G. thermodenitrificans $(n=9)$; 10 , G. thermoglucosidasius $(n=8)$; $11, G$. thermoleovorans $(n=11) ; 12$, G. toebii $(n=6) ; 13$, G. uzenensis $(n=2)$. Data for G. uzenensis were taken from Logan et al. (2009); all other data were obtained in the course of the present study.,$+>85 \%$ strains positive;,$- 0-15 \%$ strains positive; $+/ \mathrm{w}$, positive or weakly positive; w, weak reaction; $\mathrm{w} /-$, weak or negative; $\mathrm{d}$, different strains give different reactions; $\mathrm{d}(\mathrm{w})$, different strains give different reactions, but positive reactions are weak; $\mathrm{v}$, result varies within strains; ND, no data available.

\begin{tabular}{|c|c|c|c|c|c|c|c|c|c|c|c|c|c|}
\hline Character & 1 & 2 & 3 & 4 & 5 & 6 & 7 & 8 & 9 & 10 & 11 & 12 & 13 \\
\hline \multicolumn{14}{|l|}{ Sporangia } \\
\hline Cylindrical spores & - & + & $\mathrm{V}$ & + & - & - & - & $\mathrm{d}$ & - & $\mathrm{d}$ & - & - & - \\
\hline Sporangia swollen & $\mathrm{V}$ & - & + & + & $\mathrm{V}$ & - & + & - & - & $\mathrm{d}$ & - & + & $\mathrm{d}$ \\
\hline Spores subterminal & + & + & - & - & + & + & - & $\mathrm{d}$ & + & + & + & - & - \\
\hline Spores terminal & + & + & + & + & - & $\mathrm{V}$ & + & + & + & + & + & + & + \\
\hline Spores central/paracentral & - & - & + & - & - & - & - & $\mathrm{d}$ & - & - & - & - & - \\
\hline \multicolumn{14}{|l|}{ Hydrolysis of: } \\
\hline Aesculin & $+/ \mathrm{w}$ & + & + & + & + & + & + & + & + & + & + & - & + \\
\hline Casein & $+/ \mathrm{w}$ & + & $\mathrm{V}$ & $\mathrm{V}$ & + & - & - & - & - & - & $\mathrm{d}$ & - & - \\
\hline Gelatin & + & + & + & + & + & + & - & + & $\mathrm{d}$ & + & + & + & + \\
\hline ONPG & - & - & - & + & - & - & + & - & - & - & $\mathrm{d}$ & - & - \\
\hline Starch & + & $+/ \mathrm{w}$ & + & - & + & + & + & - & $+/ \mathrm{w}$ & $\mathrm{d}(\mathrm{w})$ & + & $+/ \mathrm{w}$ & + \\
\hline Catalase & + & + & + & - & - & + & + & + & + & + & + & + & ND \\
\hline Oxidase & - & + & + & + & + & - & - & + & - & $\mathrm{w}$ & + & + & ND \\
\hline Nitrate reduction & $\mathrm{d}$ & - & + & - & + & + & - & $\mathrm{d}$ & $\mathrm{d}$ & $\mathrm{d}$ & + & + & + \\
\hline Voges-Proskauer reaction & + & + & - & - & - & - & - & + & $\mathrm{d}$ & $\mathrm{d}$ & $\mathrm{d}(\mathrm{w})$ & + & - \\
\hline \multicolumn{14}{|l|}{ Acid from: } \\
\hline$N$-Acetylglucosamine & - & + & - & + & - & - & + & $\mathrm{d}$ & - & + & $\mathrm{d}$ & - & - \\
\hline Amygdalin & - & - & + & + & - & - & + & + & - & $\mathrm{d}$ & - & - & - \\
\hline L-Arabinose & - & - & + & - & + & - & + & - & $\mathrm{d}(\mathrm{w})$ & $\mathrm{d}$ & - & - & + \\
\hline Arbutin & - & $\mathrm{V}$ & + & $\mathrm{w}$ & - & - & + & + & - & $\mathrm{d}$ & - & - & $\mathrm{W}$ \\
\hline Cellobiose & - & + & + & + & + & + & + & + & + & + & $\mathrm{d}$ & - & + \\
\hline Galactose & $\mathrm{w}$ & + & + & + & + & + & + & + & - & - & $\mathrm{d}$ & + & + \\
\hline Gentiobiose & - & - & + & + & - & - & + & - & - & $\mathrm{d}$ & - & - & - \\
\hline Glycerol & $\mathrm{W}$ & + & $\mathrm{W}$ & - & + & + & + & + & - & $\mathrm{w}$ & + & - & + \\
\hline Glycogen & + & + & + & - & - & + & - & - & - & - & $\mathrm{d}$ & - & + \\
\hline Lactose & - & - & + & + & - & - & + & - & - & $\mathrm{W}$ & $\mathrm{d}(\mathrm{w})$ & - & - \\
\hline myo-Inositol & - & - & - & - & - & + & + & - & - & - & $\mathrm{d}$ & - & - \\
\hline Mannitol & - & + & - & - & + & + & - & + & $\mathrm{w}$ & + & $\mathrm{d}$ & $\mathrm{W}$ & + \\
\hline Melezitose & + & - & - & - & + & + & + & + & $\mathrm{d}(\mathrm{w})$ & - & $\mathrm{d}(\mathrm{w})$ & - & - \\
\hline Melibiose & + & - & + & - & - & - & + & + & $\mathrm{d}$ & - & $\mathrm{d}$ & $\mathrm{d}$ & - \\
\hline Methyl D-glucoside & + & - & $\mathrm{w}$ & - & + & - & + & $\mathrm{d}$ & - & + & $\mathrm{d}$ & - & + \\
\hline Raffinose & + & - & + & - & - & - & + & + & - & - & $\mathrm{d}$ & - & - \\
\hline Ribose & - & + & + & - & + & - & $\mathrm{w}$ & + & $\mathrm{w}$ & + & + & $\mathrm{d}$ & - \\
\hline Salicin & - & + & + & + & - & + & + & + & $\mathrm{d}$ & + & w & - & + \\
\hline Sucrose & + & + & + & - & + & + & + & + & $\mathrm{d}$ & + & $\mathrm{d}$ & $\mathrm{d}$ & + \\
\hline Trehalose & + & + & + & $\mathrm{ND}$ & + & + & + & + & $\mathrm{d}$ & + & $\mathrm{d}$ & + & + \\
\hline Turanose & + & $\mathrm{w}$ & + & $\mathrm{w}$ & + & - & + & - & - & + & - & - & - \\
\hline D-Xylose & - & + & + & $\mathrm{w}$ & + & + & + & - & $\mathrm{W}$ & + & $\mathrm{d}$ & - & - \\
\hline Anaerobic growth & $\mathrm{w} /-$ & - & $+/ \mathrm{w}$ & - & $\mathrm{w}$ & + & + & $\mathrm{w}$ & + & + & $\mathrm{w}$ & + & + \\
\hline \multicolumn{14}{|l|}{ Growth at/in: } \\
\hline pH 5 & - & + & + & - & + & - & - & + & - & - & $\mathrm{w}$ & - & - \\
\hline $\mathrm{pH} 9$ & + & + & + & + & + & - & + & + & + & $\mathrm{w}$ & $\mathrm{w}$ & + & - \\
\hline $1 \% \mathrm{NaCl}(\mathrm{w} / \mathrm{v})$ & + & - & + & - & + & + & + & + & - & - & $\mathrm{d}$ & + & + \\
\hline $5 \% \mathrm{NaCl}(\mathrm{w} / \mathrm{v})$ & - & - & - & - & + & - & - & + & - & - & - & - & - \\
\hline $37^{\circ} \mathrm{C}$ & $\mathrm{W}$ & + & - & - & - & + & - & + & - & - & $\mathrm{d}$ & - & - \\
\hline $70{ }^{\circ} \mathrm{C}$ & $\mathrm{d}$ & + & + & + & + & + & - & + & + & - & $\mathrm{d}$ & + & - \\
\hline Optimum temperature $\left({ }^{\circ} \mathrm{C}\right)$ & $40-60$ & 60 & $50-65$ & $>60$ & 60 & $55-60$ & 55 & 60 & 50 & 50 & 60 & 60 & $55-60$ \\
\hline
\end{tabular}


99.5\% between ' $G$. zalihae' $\mathrm{T} 1$ and $G$. thermoleovorans R-35636 ${ }^{\mathrm{T}}$ (Fig. 1).

B. thermocatenulatus was described by Golovacheva et al. (1975), but later was classed as species incertae sedis by Claus \& Berkeley (1986). Nazina et al. (2001) transferred it to Geobacillus on the basis of $16 \mathrm{~S}$ rRNA gene sequence and DNA relatedness data. Subsequently, Nazina et al. (2004) proposed G. gargensis to accommodate a novel isolate from a hot spring. They found $99.0 \% 16 \mathrm{~S}$ rRNA gene sequence similarity between the type strains of $G$. thermocatenulatus and G. gargensis, similar FAME profiles and many shared phenotypic characteristics; however, a DNA relatedness value of $43 \%$ for the two type strains supported their proposal of a novel species. In the present work, $G$. gargensis $\mathrm{R}-35649^{\mathrm{T}}$ and $G$. thermocatenulatus $\mathrm{R}-35648^{\mathrm{T}}$ clustered at $94.5 \% S_{\mathrm{G}}$ on the basis of phenotypic characters and at $98.9 \% S_{\mathrm{P}}$ on the basis of $16 \mathrm{~S}$ rRNA gene sequence analysis (Fig. 1) and showed $85.6 \%$ DNA relatedness. The phylogenetic tree (Fig. 1) shows slight differences between the 16S rRNA gene sequences of G. gargensis strains $\mathrm{Ga}^{\mathrm{T}}$ (GenBank accession no. AY193888) and R-35649 ${ }^{\mathrm{T}}$ (FN428695); however, close examination of the sequence represented by AY193888 reveals a long stretch of undefined bases (positions 874-907), whereas these positions have been determined in sequence FN428695. We therefore conclude that Geobacillus gargensis Nazina et al. 2004 is a later heterotypic synonym of Geobacillus thermocatenulatus (Golovacheva et al. 1991) Nazina et al. 2001, and an emended description is given below; characters that differentiate the species from other members of the genus are shown in Table 2 .

Strain R-32643, received as G. stearothermophilus, showed 98.9 and $99.2 \% S_{\mathrm{P}}$ in $16 \mathrm{~S}$ rRNA gene sequence, respectively, with the type strains of G. stearothermophilus and G. thermoleovorans. Despite these high levels of similarity, the strain could not be identified, since its position in the phylogenetic tree indicates a clear separation between the G. thermoleovorans group and strain R32643 (Fig. 1). Four cultures received as G. kaustophilus were believed to be misnamed. Strains R-32635 and R32504 showed 98.7 and $99.2 \% S_{\mathrm{P}}$ 16S rRNA gene sequence similarity, respectively, with the type strain of $G$. stearothermophilus (Fig. 1). DNA relatedness between R32635 and R-32504 was 67.1\%, and the DNA-DNA relatedness with G. stearothermophilus $\mathrm{R}-35646^{\mathrm{T}}$ was 72.4 and $66.4 \%$, respectively. Thus R-32504 is clearly a member of G. stearothermophilus, while R-32635 lies at the margin of this species. Strains R-32636 and R-32637, both isolated from the Lake Taupo volcanic region in New Zealand and received as G. kaustophilus, showed high phenotypic (96\% $\left.S_{\mathrm{G}}\right)$ and genotypic $\left(99.9 \% S_{\mathrm{P}}\right)$ similarity to each other, but were distinct from all the other taxa studied; however, R32637 showed $99.2 \% \quad S_{\mathrm{P}}$ with the type strain of Anoxybacillus rupiensis (Derekova et al., 2007) in $16 \mathrm{~S}$ rRNA gene sequence analysis, so these Lake Taupo isolates probably belong to A. rupiensis.

\section{Emended description of Geobacillus thermoleovorans (Zarilla and Perry 1988) Nazina et al. 2001}

Basonym: Bacillus thermoleovorans Zarilla and Perry 1988. Effective publication: Zarilla \& Perry (1987).

Geobacillus thermoleovorans [ther.mo'le.o.vo'rans. Gr. n. therme heat; L. n. oleum oil; L. v. vorare to devour; N.L. pres. part. thermoleovorans indicating heat-requiring bacteria capable of utilizing oil (hydrocarbons)].

Gram-positive, rod-shaped cells, $0.7-1.5 \times 2-6 \mu \mathrm{m}$. Some strains are peritrichously motile. Ellipsoidal endospores are borne terminally and subterminally and do not swell the sporangia. Facultatively anaerobic, but growth is weak in the absence of oxygen. Colonies are circular, creamy white in colour, with smooth and glossy or rough surfaces, entire or irregular margins, $0.5-5 \mathrm{~mm}$ in diameter, following incubation at $60{ }^{\circ} \mathrm{C}$ for $18-24 \mathrm{~h}$. Grows between $37-40{ }^{\circ} \mathrm{C}$ and $65-70{ }^{\circ} \mathrm{C}$, with optimum growth at $60{ }^{\circ} \mathrm{C}$; no growth at 30 or $80{ }^{\circ} \mathrm{C}$. Grows sparsely at pH 5 and 9; optimum growth at $\mathrm{pH}$ 6-7. Tolerates $0.5-1 \% \mathrm{NaCl}$. Catalase and oxidase are positive. Aesculin and starch are hydrolysed. Casein hydrolysis is variable. In the API 20E strip, gelatin is hydrolysed and nitrate is reduced; the ONPG test is variable, the Voges-Proskauer test is variable and weak when positive and citrate utilization (Simmons'), arginine dihydrolase, hydrogen sulfide production, indole production, lysine decarboxylase, ornithine decarboxylase, tryptophan deaminase and urease production are negative. In the API 50CHB gallery, acid without gas is produced from D-fructose, D-glucose, glycerol, maltose, D-mannose and ribose. Acid is produced weakly from salicin and acid production is variable from cellobiose, galactose, glycogen, mannitol, melezitose (weak when positive), melibiose, myo-inositol, lactose (weak when positive), methyl Dglucoside, $N$-acetylglucosamine, raffinose, starch, sucrose, trehalose and D-xylose. No acid is produced from adonitol, amygdalin, D- or L-arabinose, D- or L-arabitol, arbutin, dulcitol, erythritol, D- or L-fucose, gentiobiose, gluconate, inulin, 2- or 5-keto-D-gluconate, D-lyxose, methyl Dmannoside, methyl xyloside, rhamnose, sorbitol, L-sorbose, D-tagatose, turanose, xylitol or L-xylose. The following carbohydrates are assimilated: cellobiose, D-fructose, Dgalactose, gentiobiose, D-glucose, lactose, maltitol, maltose, maltotriose, mannitol, D-mannose, melezitose, melibiose, 1-O-methyl $\beta$-D-glucopyranoside, palatinose, D-ribose, sucrose, trehalose and turanose; assimilation is variable from aesculin, glycerol, myo-inositol, lactulose, D-lyxose, 1-O- and 3-O-methyl $\alpha$-D-glucopyranoside, 1-O-methyl $\alpha$-galactopyranoside (weak when positive), 1-O-methyl $\beta$ glucopyranoside, raffinose and $\mathrm{D}$-xylose and negative for adonitol, L-arabinose, D- and L-arabitol, dulcitol, erythritol, L-fucose, L-rhamnose, D-sorbitol, L-sorbose, D-tagatose and xylitol. The following organic acids are assimilated: $\mathrm{N}$ acetylglucosamine, fumarate, D-gluconate, DL-glycerate, DL- $\beta$-hydroxybutyrate (3-hydroxybutyrate), L-malate and succinate; assimilation is variable for 2-keto-D-gluconate 
(weak when positive), DL-lactate, D-malate (weak when positive), phenylacetate and quinate and negative for cisand trans-aconitate, 4-aminobutyrate, 4-aminovalerate, benzoate, caprate, caprylate, citrate, $m$-coumarate, $\mathrm{D}$ galacturonate, gentisate, D-glucuronate, glutarate, 3- and 4 -hydroxybenzoate, itaconate, $\alpha$-ketoglutarate, 5 -ketoD-gluconate, malonate, mucate, 3-phenylpropionate, propionate, protocatechuate, D-saccharate, D-, L- and meso-tartrate and tricarballylate. The following amino acids are assimilated: D-glucosamine, L-glutamate and L-histidine; assimilation is variable for $\mathrm{D}$ - and $\mathrm{L}$-alanine, histamine (weak when positive), L-proline (weak when positive) and L-serine and negative for L-aspartate, betaine, ethanolamine, putrescine, trigonelline, tryptamine, L-tryptophan and L-tyrosine. In the variable reactions listed above, the type strain displays the following reactions. Positive for hydrolysis of casein, negative for ONPG and positive for the Voges-Proskauer reaction. Acid is produced from galactose, glycogen, mannitol, melezitose (weakly), melibiose, myo-inositol, raffinose, starch, sucrose, trehalose and D-xylose; acid is not produced from cellobiose, lactose, methyl D-glucoside or $\mathrm{N}$-acetylglucosamine. Positive for assimilation of aesculin, glycerol, myo-inositol, lactulose (weak), 1-O-methyl $\beta$ glucopyranoside, raffinose, D-xylose, DL-lactate, phenylacetate, quinate, $\mathrm{D}$ - and L-alanine, $\mathrm{L}$-proline and L-serine and negative for assimilation of D-lyxose, 1-O- and 3-O-methyl $\alpha$-D-glucopyranoside, 1 -O-methyl $\alpha$-galactopyranoside, 2-keto-D-gluconate, D-malate and histamine. The major cellular fatty acids are iso- $C_{15: 0}$, iso- $C_{16: 0}$ and iso- $C_{17: 0}$. Strains have been isolated from pasteurized milk, geothermally heated pools and springs and associated soil, marine sediment of a hydrothermal vent and crude oil. The DNA $\mathrm{G}+\mathrm{C}$ content is $52-53 \mathrm{~mol} \%$ ( $52.4 \mathrm{~mol} \%$ for the type strain; HPLC). The EMBL/GenBank/DDBJ accession number for the 16S rRNA gene sequence of the type strain (DSM $5366^{\mathrm{T}}$ ) is $\mathrm{Z} 26923$.

Type strain: LEH $^{-1}{ }^{\mathrm{T}} \quad\left(=\right.$ LMG $9823^{\mathrm{T}}=$ ATCC $43513^{\mathrm{T}}$ $=$ DSM $5366^{\mathrm{T}}$ ).

\section{Emended description of Geobacillus thermocatenulatus (Golovacheva et al. 1991) Nazina et al. 2001}

Basonym: Bacillus thermocatenulatus Golovacheva et al. 1991. Effective publication: Golovacheva et al. (1975).

Geobacillus thermocatenulatus (ther.mo.ca.te'nu.la.tus. Gr. n. therme heat; N.L. adj. catenulatus chain-like; N.L. masc. adj. thermocatenulatus thermophilic and chain-like, referring to two of the organism's features).

Gram-positive, peritrichously motile rods, $0.9-1.5 \times 6-$ $12 \mu \mathrm{m}$. The description is based on two strains. Facultatively anaerobic, but growth is weak in the absence of oxygen. Cells occur singly or in long chains. Ellipsoidal or cylindrical spores are located terminally, occasionally subterminally and paracentrally, and do not swell the sporangia. Colonies on TSA are butyrous, cream or yellowish in colour, round and raised with entire margins; may become partially heaped-up and viscid. Growth can occur at 37 and $80{ }^{\circ} \mathrm{C}$, with optimum growth at $60{ }^{\circ} \mathrm{C}$. Tolerates $5 \%$ but not $7 \% \mathrm{NaCl}$. Grows at $\mathrm{pH} 5$ and 9 , and optimally at $\mathrm{pH}$ 7. Aesculin is hydrolysed; casein and starch are not hydrolysed. Catalase and oxidase are positive. In the API 20E strip, gelatin is hydrolysed and the Voges-Proskauer test is positive; citrate utilization (Simmons') and nitrate reduction are variable and arginine dihydrolase, hydrogen sulfide, indole, lysine decarboxylase, ornithine decarboxylase, ONPG, tryptophan deaminase and urease production are negative. In the API $50 \mathrm{CHB}$ gallery, acid without gas is produced from amygdalin, arbutin, cellobiose, D-fructose, galactose, D-glucose, glycerol, maltose, mannitol, D-mannose, melezitose, melibiose, raffinose, ribose, salicin, starch, sucrose and trehalose. Acid production is variable from methyl D-glucoside and $\mathrm{N}$-acetylglucosamine. Acid production is negative from adonitol, D- and L-arabinose, D- and L-arabitol, dulcitol, erythritol, D- and L-fucose, gentiobiose, gluconate, glycogen, inulin, 2- and 5-keto-D-gluconate, lactose, D-lyxose, myo-inositol, methyl D-mannoside, methyl xyloside, rhamnose, sorbitol, L-sorbose, D-tagatose, turanose, xylitol and D- and L-xylose. In the variable reactions listed above, the type strain produces acid from methyl D-glucoside and $\mathrm{N}$-acetylglucosamine and does not utilize citrate or reduce nitrate. A number of hydrocarbons $\left(\mathrm{C}_{10}-\mathrm{C}_{16}\right)$ may be utilized as carbon and energy sources. The major cellular fatty acids are iso- $\mathrm{C}_{15: 0}$, iso- $\mathrm{C}_{16: 0}$ and iso- $\mathrm{C}_{17: 0}$, making up more than $60 \%$ of the total fatty acids (Nazina et al., 2001). The DNA G + C content of the type strain is $51.17 \mathrm{~mol} \%$ (HPLC). The EMBL/GenBank/ DDBJ accession number for the 16S rRNA gene sequence of the type strain $\left(\right.$ BGSC $93^{\mathrm{T}}$ ) is AY608935.

The type strain is strain $178^{\mathrm{T}}\left(=\mathrm{LMG} 19007^{\mathrm{T}}=\mathrm{DSM} 730^{\mathrm{T}}\right.$ $=$ VKM B $-1259^{\mathrm{T}}=$ BGSC $\left.93^{\mathrm{T}}\right)$, isolated from a slime layer inside a hot-gas borehole pipe; another strain $(\mathrm{Ga}=\mathrm{DSM}$ $15378=$ VKM B-2300) was isolated from the Garga hot spring in the Transbaikal region, Russia.

\section{Acknowledgements}

The type strain of G. lituanicus was kindly donated by Dr N. Kuisiene (Dept of Plant Physiology and Microbiology, Vilnius University, Lithuania). A.E.D. and G.H. gratefully acknowledge the support of bioMérieux, Inc.

\section{References}

Abd Rahman, R. N., Leow, T. C., Salleh, A. B. \& Basri, M. (2007). Geobacillus zalihae sp. nov., a thermophilic lipolytic bacterium isolated from palm oil mill effluent in Malaysia. BMC Microbiol $7,77$.

Allan, R. N., Lebbe, L., Heyrman, J., De Vos, P., Buchanan, C. J. \& Logan, N. A. (2005). Brevibacillus levickii sp. nov. and Aneurinibacillus terranovensis sp. nov., two novel thermoacidophiles isolated from geothermal soils of northern Victoria Land, Antarctica. Int J Syst Evol Microbiol 55, 1039-1050. 
Ash, C., Farrow, J. A. E., Wallbanks, S. \& Collins, M. D. (1991). Phylogenetic heterogeneity of the genus Bacillus revealed by comparative analyses of small subunit-ribosomal RNA sequences. Lett Appl Microbiol 13, 202-206.

Caccamo, D., Gugliandolo, C., Stackebrandt, E. \& Maugeri, T. L. (2000). Bacillus vulcani sp. nov., a novel thermophilic species isolated from a shallow marine hydrothermal vent. Int J Syst Evol Microbiol 50, 2009-2012.

Claus, D. \& Berkeley, R. C. W. (1986). Genus Bacillus Cohn 1872. In Bergey's Manual of Systematic Bacteriology, vol. 2, pp. 1105-1139. Edited by P. H. A. Sneath, N. S. Mair, M. E. Sharpe \& J. G. Holt. Baltimore: Williams \& Wilkins.

Derekova, A., Sjøholm, C., Mandeva, R. \& Kambourova, M. (2007). Anoxybacillus rupiensis sp. nov., a novel thermophilic bacterium isolated from Rupi basin (Bulgaria). Extremophiles 11, 577-583.

Ezaki, T., Hashimoto, Y. \& Yabuuchi, E. (1989). Fluorometric deoxyribonucleic acid-deoxyribonucleic acid hybridization in microdilution wells as an alternative to membrane filter hybridization in which radioisotopes are used to determine genetic relatedness among bacterial strains. Int J Syst Bacteriol 39, 224-229.

Golovacheva, R. S., Loginova, L. G., Salikhov, T. A., Kolesnikov, A. A. \& Zaitseva, G. N. (1975). A new thermophilic species, Bacillus thermocatenulatus nov. spec. Microbiology (English translation of Mikrobiologiia) 44, 230-233.

Golovacheva, R. S., Loginova, L. G., Salikhov, T. A., Kolesnikov, A. A \& Zaitseva, G. N. (1991). Bacillus thermocatenulatus sp. nov. In Validation of the Publication of New Names and New Combinations Previously Effectively Published Outside the IJSB, List no. 36. Int J Syst Bacteriol 41, 178-179.

Gower, J. C. (1971). A general coefficient of similarity and some of its properties. Biometrics 27, 857-874.

Guindon, S. \& Gascuel, O. (2003). A simple, fast, and accurate algorithm to estimate large phylogenies by maximum likelihood. Syst Biol 52, 696-704.

Heinen, U. J. \& Heinen, W. (1972). Characteristics and properties of a caldo-active bacterium producing extracellular enzymes and two related strains. Arch Mikrobiol 82, 1-23.

Heyrman, J. \& Swings, J. (2001). 16S rDNA sequence analysis of bacterial isolates from biodeteriorated mural paintings in the Servilia tomb (Necropolis of Carmona, Seville, Spain). Syst Appl Microbiol 24, 417-422.

Kämpfer, P., Rosselló-Mora, R., Falsen, E., Busse, H.-J. \& Tindall, B. J. (2006). Cohnella thermotolerans gen. nov., sp. nov., and classification of 'Paenibacillus hongkongensis' as Cohnella hongkongensis sp. nov. Int J Syst Evol Microbiol 56, 781-786.

Kuisiene, N., Raugalas, J. \& Chitavichius, D. (2004). Geobacillus lituanicus sp. nov. Int J Syst Evol Microbiol 54, 1991-1995.

Logan, N. A. \& Berkeley, R. C. W. (1984). Identification of Bacillus strains using the API system. J Gen Microbiol 130, 1871-1882.

Logan, N. A. \& De Vos, P. (2009). Genus I. Bacillus Cohn 1872, $174^{\mathrm{AL}}$ In Bergey's Manual of Systematic Bacteriology, 2nd edn, vol. 3, pp. 21128. Edited by P. De Vos, G. M. Garrity, D. Jones, N. R. Krieg, W. Ludwig, F. A. Rainey, K.-H. Schleifer \& W. B. Whitman. New York: Springer.

Logan, N. A., Lebbe, L., Hoste, B., Goris, J., Forsyth, G., Heyndrickx, M., Murray, B. L., Syme, N., Wynn-Williams, D. D. \& De Vos, P. (2000). Aerobic endospore-forming bacteria from geothermal environments in northern Victoria Land, Antarctica, and Candlemas Island, South Sandwich archipelago, with the proposal of Bacillus fumarioli sp. nov. Int J Syst Evol Microbiol 50, 1741-1753.

Logan, N. A., De Vos, P. \& Dinsdale, A. E. (2009). Genus VII. Geobacillus Nazina, Tourova, Poltaraus, Novikova, Grigoryan, Ivanova, Lysenko, Petrunyaka, Osipov, Belyaev and Ivanov 2001, $442^{\mathrm{VP}}$. In Bergey's Manual of Systematic Bacteriology, 2nd edn, vol. 3, pp. 144-160. Edited by P. De Vos, G. M. Garrity, D. Jones, N. R. Krieg, W. Ludwig, F. A. Rainey, K.-H. Schleifer \& W. B. Whitman. New York: Springer.

Mesbah, M., Premachandran, U. \& Whitman, W. B. (1989). Precise measurement of the $\mathrm{G}+\mathrm{C}$ content of deoxyribonucleic acid by highperformance liquid chromatography. Int J Syst Bacteriol 39, 159-167.

Miñana-Galbis, D., Pinzón, D. L., Lorén, J. G., Manresa, Á. \& OliartRos, R. M. (2010). Reclassification of Geobacillus pallidus (Scholz et al. 1988) Banat et al. 2004 as Aeribacillus pallidus gen. nov., comb. nov. Int J Syst Evol Microbiol 60, 1600-1604.

Nazina, T. N., Tourova, T. P., Poltaraus, A. B., Novikova, E. V., Grigoryan, A. A., Ivanova, A. E., Lysenko, A. M., Petrunyaka, V. V., Osipov, G. A. \& other authors (2001). Taxonomic study of aerobic thermophilic bacilli: descriptions of Geobacillus subterraneus gen. nov., sp. nov. and Geobacillus uzenensis sp. nov. from petroleum reservoirs and transfer of Bacillus stearothermophilus, Bacillus thermocatenulatus, Bacillus thermoleovorans, Bacillus kaustophilus, Bacillus thermoglucosidasius and Bacillus thermodenitrificans to Geobacillus as the new combinations G. stearothermophilus, G. thermocatenulatus, G. thermoleovorans, G. kaustophilus, G. thermoglucosidasius and G. thermodenitrificans. Int J Syst Evol Microbiol 51, 433-446.

Nazina, T. N., Lebedeva, E. V., Poltaraus, A. B., Tourova, T. P., Grigoryan, A. A., Sokolova, D. Sh., Lysenko, A. M. \& Osipov, G. A. (2004). Geobacillus gargensis sp. nov., a novel thermophile from a hot spring, and the reclassification of Bacillus vulcani as Geobacillus vulcani comb. nov. Int J Syst Evol Microbiol 54, 2019-2024.

Nazina, T. N., Sokolova, D. Sh., Grigoryan, A. A., Shestakova, N. M., Mikhailova, E. M., Poltaraus, A. B., Tourova, T. P., Lysenko, A. M., Osipov, G. A. \& Belyaev, S. S. (2005). Geobacillus jurassicus sp. nov., a new thermophilic bacterium isolated from a high-temperature petroleum reservoir, and the validation of the Geobacillus species. Syst Appl Microbiol 28, 43-53.

Priest, F. G., Goodfellow, M. \& Todd, C. (1989). Bacillus kaustophilus sp. nov. In Validation of the Publication of New Names and New Combinations Previously Effectively Published Outside the IJSB, List no. 28. Int J Syst Bacteriol 39, 93-94.

Rainey, F. A., Fritze, D. \& Stackebrandt, E. (1994). The phylogenetic diversity of thermophilic members of the genus Bacillus as revealed by $16 \mathrm{~S}$ rDNA analysis. FEMS Microbiol Lett 115, 205-211.

Romano, I., Poli, A., Lama, L., Gambacorta, A. \& Nicolaus, B. (2005). Geobacillus thermoleovorans subsp. stromboliensis subsp. nov., isolated from the geothermal volcanic environment. J Gen Appl Microbiol 51, 183-189.

Sharp, R. J., Bown, K. J. \& Atkinson, A. (1980). Phenotypic and genotypic characterization of some thermophilic species of Bacillus. J Gen Microbiol 117, 201-210.

Sunna, A., Tokajian, S., Burghardt, J., Rainey, F., Antranikian, G. \& Hashwa, F. (1997). Identification of Bacillus kaustophilus, Bacillus thermocatenulatus and Bacillus strain HSR as members of Bacillus thermoleovorans. Syst Appl Microbiol 20, 232-237.

Tamura, K., Dudley, J., Nei, M. \& Kumar, S. (2007). MEGA4: molecular evolutionary genetics analysis (MEGA) software version 4.0. Mol Biol Evol 24, 1596-1599.

Tindall, B. J. (1990a). Lipid composition of Halobacterium lacusprofundi. FEMS Microbiol Lett 66, 199-202.

Tindall, B. J. (1990b). A comparative study of the lipid composition of Halobacterium saccharovorum from various sources. Syst Appl Microbiol 13, 128-130.

Vauterin, L., Yang, P., Hoste, B., Vancanneyt, M., Civerolo, E. L., Swings, J. \& Kersters, K. (1991). Differentiation of Xanthomonas campestris pv. citri strains by sodium dodecyl sulfate-polyacrylamide gel electrophoresis of proteins, fatty acid analysis, and DNA-DNA hybridization. Int J Syst Bacteriol 41, 535-542. 
White, D., Sharp, R. J. \& Priest, F. G. (1993). A polyphasic taxonomic study of thermophilic bacilli from a wide geographical area. Antonie van Leeuwenhoek 64, 357-386.

Willems, A., Doignon-Bourcier, F., Goris, J., Coopman, R., de Lajudie, P., De Vos, P. \& Gillis, M. (2001). DNA-DNA hybridization study of Bradyrhizobium strains. Int $J$ Syst Evol Microbiol 51, 1315-1322.

Zarilla, K. A. \& Perry, J. J. (1987). Bacillus thermoleovorans, sp. nov., a species of obligately thermophilic hydrocarbon utilizing endosporeforming bacteria. Syst Appl Microbiol 9, 258-264.
Zarilla, K. A. \& Perry, J. J. (1988). Bacillus thermoleovorans sp. nov. In Validation of the Publication of New Names and New Combinations Previously Effectively Published Outside the IJSB, List no. 25. Int J Syst Bacteriol 38, 220-222.

Zeigler, D. R. (2005). Application of a recN sequence similarity analysis to the identification of species within the bacterial genus Geobacillus. Int J Syst Evol Microbiol 55, 1171-1179.

Zhou, Y., Xu, J., Xu, L. \& Tindall, B. J. (2009). Falsibacillus pallidus to replace the homonym Bacillus pallidus Zhou et al. 2008. Int J Syst Evol Microbiol 59, 3176-3180. 